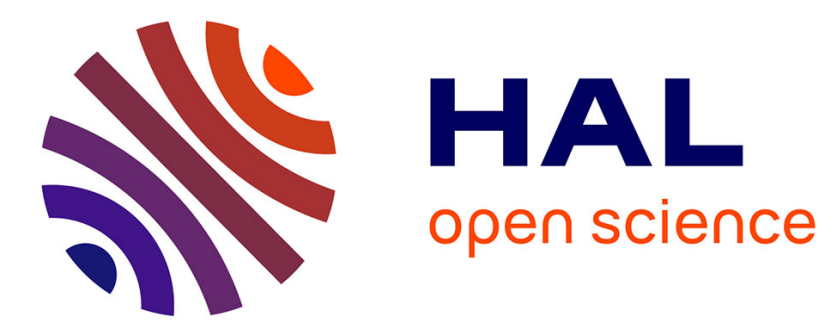

\title{
How Do Spouses Share their Full Income in Russia?: Identification of the Sharing Rule Using Self-reported Income
}

Ekaterina Kalugina, Natalia Radtchenko, Catherine Sofer

\section{- To cite this version:}

Ekaterina Kalugina, Natalia Radtchenko, Catherine Sofer. How Do Spouses Share their Full Income in Russia?: Identification of the Sharing Rule Using Self-reported Income. Review of Income and Wealth, 2009, 55 (2), pp.360-391. 10.1111/j.1475-4991.2009.00323.x . halshs-00368422

\section{HAL Id: halshs-00368422 \\ https://shs.hal.science/halshs-00368422}

Submitted on 16 Mar 2009

HAL is a multi-disciplinary open access archive for the deposit and dissemination of scientific research documents, whether they are published or not. The documents may come from teaching and research institutions in France or abroad, or from public or private research centers.
L'archive ouverte pluridisciplinaire HAL, est destinée au dépôt et à la diffusion de documents scientifiques de niveau recherche, publiés ou non, émanant des établissements d'enseignement et de recherche français ou étrangers, des laboratoires publics ou privés. 


\title{
How Do Spouses Share their Full Income in Russia?:
}

\section{Identification of the Sharing Rule Using Self-reported Income}

\author{
Ekaterina Kalugina ${ }^{1}$ (University of Paris 1-Panthéon-Sorbonne, CNRS, and HCE, Moscow) \\ Natalia Radtchenko ${ }^{2}$ (University of Paris 1-Panthéon-Sorbonne, CNRS, \& CREST-LMI) \\ Catherine Sofer ${ }^{3}$ (University of Paris 1-Panthéon-Sorbonne, CNRS, and Paris School of \\ Economics)
}

January 2007

The paper applies the collective model to the analysis of intra-household inequality using selfreported income scales and provides a test for its assumptions. We assume a correspondence between the income level that household members report and their true income sharing. Using Russian data, we first show that this assumption is supported by the data, and then use couples who report the same level of income to identify the full sharing rule for the whole sample. From simulations for an average couple living in the Urals, we find that a full income share of $45 \%$ is allocated to the wife.

JEL Classification: D1, J22, C3.

Keywords: Collective model, Within-household income comparisons, Subjective data, Russia, Sharing rule.

\footnotetext{
${ }^{1}$ CES, Maison des Sciences Economiques, 106-112, bd de 1'Hôpital, 75647 PARIS cedex 13, France. Tel: 00331-44-07-82-52. E-mail: Ekaterina.Kalugina@malix.univ-paris1.fr

${ }^{2}$ CES, Maison des Sciences Economiques, 106-112, bd de 1'Hôpital, 75647 PARIS cedex 13, France. Tel: 00331-44-07-82-52. E-mail: Natalia.Radtchenko@malix.univ-paris1.fr

${ }^{3}$ CES, Maison des Sciences Economiques, 106-112, bd de 1'Hôpital, 75647 PARIS cedex 13, France. Tel: 0033 1-44-07-82-58. E-mail: Catherine.Sofer@univ-paris1.fr
} 


\section{INTRODUCTION}

One central issue in applications of the economics of the household to policy analysis is that of within-household welfare comparisons and, in particular, of intra-family inequality. The current article examines this issue in the framework of a collective model of household behavior.

We provide an application of the collective model to the analysis of intra-household inequality, using self-reported income scales. The collective model based on the sharing rule (Chiappori, 1988, 1992 and 1997, Apps and Rees, 1997)) is used to determine empirically the intra-household allocation of resources formally represented by the sharing rule. Most of empirical applications are limited to identify the sharing rule up to a constant. This constraint comes from the non observation of the private consumption. We propose to use self-reported income scale as an additional source of identification allowing the full sharing rule retrieval.

We interpret intra-household equality as the equal ${ }^{4}$ distribution of self-reported full income between the (main two adult) members of the household. Following recent models by Apps and Rees (1997), Chiappori (1997), Rapoport, Sofer and Solaz (2003 and 2006), and Bourguignon and Chiuri (2005), not only labor and non-labor income but also the output of household production are included in the household resources to be shared. We consider that such an approach better reflects the true consumption of leisure by both members of the household than that found in more standard collective models.

Using the framework of the collective model including household production under the assumption of marketable domestic goods (Rapoport, Sofer and Solaz, 2003 and 2006), we make a number of assumptions linking self-reported income and the theoretical results of the model. More precisely, we assume that the answers to a question in the data about self-

\footnotetext{
${ }^{4}$ Taking into account potential measurement error
} 
reported income reflect the true division of income within the family. This assumption is tested and we show that it is not refuted by the data. Then from the results obtained for the sub-sample of couples reporting the same level of income, we calculate the constant of the sharing rule for the whole sample: we thus propose a new method for deriving not only the derivatives, but also the sharing rule itself (see Browning, Chiappori and Lewbel, 2004)

In recent years a large number of empirical papers have analyzed self-reported income and poverty (Ferrer-i-Carbonell and Frijters, 2004). In this paper we assume that the main reason why two members of the same family report different incomes is that they do actually end up with unequal incomes as a result of household income-sharing. Empirically, and as predicted by non-unitary models (bargaining as well as collective models), in the RLMS survey data many husbands and wives report different values of income.

After briefly presenting the collective model with household production, and setting out the predicted relationship between the sharing rule from the collective model and selfreported income data, we show that the values of the latter reported by husbands and wives are significantly different. The data come from the Russian Longitudinal Monitoring Survey (RLMS, Rounds V to VIII, 1994-1998). We test a number of alternative explanations of these discrepancies, and conclude that the data provide support to our hypothesis that differences in these subjective responses reflect real differences in income sharing. More specifically, we estimate an ordered probit model in order to explain the differences in husbands' and wives' answers. This estimation is based on the collective model with household production; as such we have to take into account the endogenous profit from household production. We estimate the model using full information maximum likelihood (FIML) and find, as expected, that the more "bargaining power" a woman has (as measured by her wage relative to her husband's, 
for example), the more likely she is to self-report a level of income higher than that reported by her husband. These results provide an original test of the collective model.

In a second stage, we estimate the total labor supplies of household members (market work plus domestic work) using 3SLS. We first use the sub-sample of households who report equal income-sharing to derive the labor supply parameters. The parameters of the sharing rule are then identified in a second stage using the whole sample. We are thus able to calculate the marginal effects of wages and non-labor income on the sharing rule: these show, in particular, that the female income share is more sensitive to female wages than to male wages. The full identification of the sharing rule allows simulating full income-sharing. For an average couple, with the husband aged 41, with one child, and living in the Urals, we find that a full income share of $45 \%$ is allocated to the wife.

The paper is organized as follows. Section 1 outlines the collective model of household labor supply with household production, based upon Rapoport, Sofer and Solaz (2003 and 2006). We then apply this model to intra-household inequality and provide a test of its main assumptions. Section 2 presents the data. In section 3, we present the method used to fully identify the sharing rule. Section 4 presents the results.

\section{THE MODEL}

In this section we derive conditions for the equal sharing of full income, starting from the collective model including household production (Apps and Rees, 1997, Rapoport, Sofer and Solaz, 2003 and 2006). Rapoport et al. propose a method for estimating the derivatives of the sharing rule under the assumption of marketable domestic goods. We extend these results to provide a method which allows the identification of the sharing rule itself. 


\subsection{The Collective Model with Household Production.}

Consider two individuals $(i=f, m)$. Each has a utility function depending on leisure (assignable and observed), $L_{\mathrm{i}}$, the consumption of a Hicksian composite good (unobserved), $C_{\mathrm{i}}$, with a normalized price of 1 , and a vector of domestic goods $\mathbf{Y}$.

Besides the composite good, $C_{i}$, purchased in the market, the household produces the vector of domestic goods, $\mathbf{Y}$. Let the production function of the $k^{\text {th }}$ domestic $\operatorname{good}^{5}$ be

$$
Y^{k}=g^{k}\left(t_{f}^{k}, t_{m ;}^{k} \mathbf{z}\right), \quad k=1, \ldots K,
$$

where $t_{i}^{k},(i=f, m)$ is member $i$ 's household work devoted to the production of domestic good $k$, and $\mathbf{z}$ is an $\mathrm{N}$-vector representing household heterogeneity. We assume that all goods are privately consumed. Individual utility can be written as: $U_{i}=U_{i}\left(L_{i}, C_{i}, \mathbf{Y}_{i} ; \mathbf{z}\right)$, where $\mathbf{Y}_{\boldsymbol{i}}$ is the vector of member $i$ 's consumption of domestic goods.

Let $t_{i},=\sum_{k} t_{i}^{k}(i=f, m)$ be the total time that household member $i$ devotes to the production of domestic goods, and $T$ the total time available. Let $\mathbf{s}$ be an R-vector of distribution factors ${ }^{6}, y$ the household's non-labor income, and $w_{f}$, and $w_{m}$ the wage rate of $f$ and $m$ respectively.

\subsubsection{The Household Maximization Problem.}

In the collective model with household production, the Pareto-efficient solution results from program $(\mathrm{P} 1)$ :

$$
\underset{L_{f}, C_{f}, Y_{f}, L_{m}, C_{m}, \mathbf{Y}_{m}}{\operatorname{Max}}\left(\mu_{f}(.) U_{f}\left(L_{f}, C_{f}, \mathbf{Y}_{f}, \ldots ; \mathbf{z}\right)+\mu_{m}(.) U_{m}\left(L_{m}, C_{m}, \mathbf{Y}_{m}, \ldots ; \mathbf{z}\right)\right)
$$

\footnotetext{
${ }^{5}$ We assume that there is no joint production in the household production sector.

${ }^{6}$ Distribution factors are variables which influence the bargaining power of household members, but neither prices nor preferences, (see Chiappori, Fortin and Lacroix, 2002).
} 
subject to

$$
C_{f}+C_{m}+\mathbf{p} \mathbf{Y}_{f}+\mathbf{p} \mathbf{Y}_{m}+L_{f} w_{f}+L_{m} w_{m} \leq T w_{f}+T w_{m}+y+\Pi\left(w_{f}, w_{m}, \mathbf{p}\right)
$$

where $\mu_{i}=\mu_{i}\left(w_{f}, w_{m}, y, \mathbf{s}, \mathbf{z}\right)$ are continuously differentiable weighting factors contained in $[0,1]$ such that $\mu_{f}+\mu_{m}=1$ with $\mathbf{s}$ being a vector of distribution factors ${ }^{7} . \Pi\left(w_{f}, w_{m}, \mathbf{p}\right)$ is the profit from household production. Assume that domestic goods are marketable: they have market substitutes and can be freely exchanged in the market. The price vector of domestic goods $\mathbf{p}$ is thus exogenous and the same for all households. Also note that, as household production can be bought or sold in the market, the total consumption of household goods by household members does not necessarily sums up to total household production

\subsubsection{Decentralization and the Sharing Rule.}

As in Apps and Rees (1997) and Chiappori (1997), the second theorem of welfare economics implies that the equilibrium corresponding to program $(\mathrm{P} 1)$ can be decentralized and the solution obtained in two stages.

First, the household determines the optimal allocation of time of each member in domestic production, using the criterion of the maximization of profit or net value of domestic production. This imputed profit is added to the other income flows. In the second stage, consumption is decentralized by the appropriate choice of shares $\Phi_{i}(i=f, m)$ of total full income. Program (P1) can thus be reformulated as (P2.1) and (P2.2):

$$
\begin{aligned}
& \underset{t_{f}, t_{m}}{\operatorname{Max}} \Pi=\mathbf{p Y}-w_{f} t_{f}-w_{m} t_{m} \\
& \underset{C_{i}, L_{i}, Y_{i}}{\operatorname{Max}} U_{i}\left(L_{i}, C_{i}, \mathbf{Y}_{i}, \ldots ; \mathbf{z}\right), \quad i=f, m
\end{aligned}
$$

\footnotetext{
${ }^{7}$ Distribution factors are variables which influence the bargaining power of household members, but neither prices nor preferences, (see Chiappori, Fortin and Lacroix, 2002).
} 
subject to budget and time constraints:

$$
\begin{aligned}
& C_{i}+\mathbf{p} \mathbf{Y}_{i}+L_{i} w_{i} \leq \Phi_{i} \\
& L_{i}+h_{i}+t_{i}=T,
\end{aligned}
$$

where the sharing rule $\Phi_{i}\left(w_{f}, w_{m}, \mathbf{p}, y ; \mathbf{s}, \mathbf{z}\right)$ represents the part of full income allocated to member $i$, with:

$$
\Phi=\Phi_{f+} \Phi_{m}=\left(w_{f}+w_{m}\right) T+y+\Pi
$$

\subsubsection{The Demands for Leisure.}

Solving program (P3) below, which is a reformulation of (P2), yields the Marshallian demands (1.2) and (1.3) for leisure. We have:

$$
\begin{aligned}
& \underset{t_{f}, t_{m}}{\operatorname{Max}} \Pi=\mathbf{p Y}-w_{f} t_{f}-w_{m} t_{m} \\
& \underset{C_{i}, L_{i}, Y_{i}}{\operatorname{Max}} U_{i}\left(L_{i}, C_{i}, \mathbf{Y}_{i}, \ldots ; \mathbf{z}\right), \quad i=f, m
\end{aligned}
$$

subject to:

$$
\begin{aligned}
& C_{f}+\mathbf{p} \mathbf{Y}_{f}+w_{f}\left(T-h_{f}\right) \leq \Phi_{f} \\
& C_{m}+\mathbf{p} \mathbf{Y}_{m}+w_{m}\left(T-h_{m}\right) \leq \Phi_{m}
\end{aligned}
$$

where $h_{i}$ is member's i working time on the market, $i=m_{\imath} f$

$$
\begin{aligned}
& \Phi_{m}+\Phi_{f}=\Phi \\
& L_{i}+h_{i}+t_{i}=T, \\
& L_{f}=L^{f}\left(w_{f}, \Phi_{f}\left(w_{f}, w_{m}, y, \mathbf{s}, \mathbf{z}\right) ; \mathbf{z}\right) \\
& L_{m}=L^{m}\left(w_{m}, \Phi-\Phi_{f}\left(w_{f}, w_{m}, y, \mathbf{s}, \mathbf{z}\right) ; \mathbf{z}\right)
\end{aligned}
$$


$L_{f}$ and $L_{m}$ are the Marshallian demands for leisure. As the price vector $\mathbf{p}$ is fixed, it is omitted from the endogenous functions of the model.

\subsection{Intra-household Income Comparisons.}

\subsubsection{Intra-household Equality and the Sharing Rule.}

Intra-household equality can be defined in a number of different ways. Assuming inter-personal utility comparisons, for example, we can consider the equality of utility between the two household members. In this paper we interpret intra-household equality as an equal distribution of the total household income defined by the collective model as the sum of monetary and non-monetary incomes (leisure being valued at the opportunity cost of work).

We use data which contain the answer to a subjective question about income. Respondents situate their income on a 9-step ladder. Making the usual assumption of no systematic bias in these replies, we directly relate their subjective answer to the income they objectively receive within the family. The assumption made here is that people's answers to this question provide information about the income share allocated to them within the household. We will discuss this assumption in depth in the next section. Assume for the time being that intra-household equality is defined as equality in the sharing of full income, which in turn is indicated by both husband and wife giving the same answer to the income question ${ }^{8}$. More precisely, we assume that:

$\Phi_{f}>\Phi_{m}$, if the wife reports a higher value of income than her husband

$\Phi_{f}<\Phi_{m}$, if she reports a lower value of income than her husband

$\Phi_{f}=\Phi_{m}$, if husband and wife report the same level of income

\footnotetext{
${ }^{8}$ The definiton we use for equality in the empirical work is slightly more complicated, as it allows for measurement errors; see section 2 below.
} 
The definitions of $\Phi_{f}$ and $\Phi_{m}$ yield the following system describing intra-household inequality:

$$
\begin{cases}\Phi_{f}<\frac{1}{2}\left[\left(w_{m}+w_{f}\right) T+y+\Pi\right], & \text { if } \Phi_{f}<\Phi_{m} \\ \Phi_{f}=\frac{1}{2}\left[\left(w_{m}+w_{f}\right) T+y+\Pi\right], & \text { if } \Phi_{f}=\Phi_{m} \\ \Phi_{f}>\frac{1}{2}\left[\left(w_{m}+w_{f}\right) T+y+\Pi\right], & \text { if } \Phi_{f}>\Phi_{m}\end{cases}
$$

\section{DO SUBJECTIVE ANSWERS REFLECT TRUE INCOME-}

\section{SHARING?}

In this section, we provide more details about the assumptions that we make. We first present the data, and then concentrate on the answers to the self-reported income question and the assumptions we make. In the last paragraph, we carry out some estimations which aim to test these assumptions.

\subsection{The data}

The data used in the econometric analysis come from the Russian Longitudinal Monitoring Survey (RLMS). This database is jointly collected by UNC Chapel Hill (USA), the Russian Academy of Sciences and the Russian Institute of Nutrition.

The survey has two phases: during the first phase of the project (1992-1994), the RLMS collected four rounds (I - IV) of data on 5900 households on average; since 1994 the RLMS has collected eight further rounds (V - XII) of data in the second phase of the project. Since the RLMS switched partners in Russia for the second phase, the second phase data were 
drawn anew from the population. The second phase sample size is approximately 4000 households. The samples in the two phases do not concern the same individuals.

Two questionnaires are given to survey respondents: a household questionnaire and an individual questionnaire. The first asks about household structure, expenditure, income, housing conditions, land use, and so on. The second covers employment, labor income, educational, satisfaction with economic conditions, etc. The individual questionnaire for rounds I - VIII (1992-1998) included a section on "Use of Time", containing questions on the amount of time devoted to household occupations in the seven days preceding the interview. These occupations are working on the individual land plot, dacha, or garden plot, excluding farm plots or a personal subsidiary farm; looking for and purchasing food items; preparing food and washing dishes; cleaning the apartment; doing laundry, ironing; looking after the children; caring for any (other) children - ones own or others'- aged 12 or under, who don't live with the interviewee and caring for whom is not part of the interviewee's job; looking after one's father who is aged over 50 (for example, going to the store, helping with cleaning, or washing clothes); looking after one's mother who is aged over 50; and helping relatives or acquaintances who are aged over 50.

We use data from rounds V-VIII (1994-1998) of phase II as we will need the time use questionnaire to include household production in the empirical analysis. The sample used for the econometric analysis consists of couples where both partners are employed and the household head is of working age. That is, men are between 16 and 59 years old and both partners work. This yields an unbalanced panel of 1480 households (household heads) with 2419 observations, as some households are observed several times. After excluding households with missing values on key variables we are left with 2144 observations. Table 1 reports the percentage of households observed for $1,2,3$ or 4 waves. More than half of households are observed only in one wave, and only $16.8 \%$ of households are observed more 
than twice. Due to the small size of the panel, we pool the data and do not control for any invariant household effects in what follows. These effects can produce biases, but given the characteristics of the data these are expected to be insignificant. By contrast, we control for the period of observation in order to take into account common aggregate time-specific shocks due to the instability of the Russian economy during transition, and in particular instability in the Russian labor market.

Table1. Frequencies of Number of Waves Observed per Household.

\begin{tabular}{|c|c|}
\hline Number of Waves Observed & Frequency (\%) \\
\hline 1 & 55.6 \\
\hline 2 & 27.6 \\
\hline 3 & 12.4 \\
\hline 4 & 4.4 \\
\hline \hline Total & 100 \\
\hline
\end{tabular}

Table 2 shows the sample means of the variables used in the econometric analysis.

Table 2. Sample Means of Variables.

\begin{tabular}{|c|c|c|c|c|c|c|}
\hline \multirow[b]{2}{*}{ Variable } & \multicolumn{3}{|c|}{ Women } & \multicolumn{3}{|c|}{ Men } \\
\hline & $\begin{array}{c}\text { Round VIII } \\
\text { Means }\end{array}$ & $\begin{array}{l}\text { Round VII } \\
\text { Means }\end{array}$ & $\begin{array}{l}\text { Round VI } \\
\text { Means }\end{array}$ & $\begin{array}{c}\text { Round VIII } \\
\text { Means }\end{array}$ & $\begin{array}{l}\text { Round VII } \\
\text { Means }\end{array}$ & $\begin{array}{l}\text { Round VI } \\
\text { Means }\end{array}$ \\
\hline $\begin{array}{l}\text { Market time per } \\
\text { week }\left(h_{\mathrm{i}}\right), \mathrm{hrs}\end{array}$ & $\begin{array}{c}38.78 \\
(15.38)\end{array}$ & $\begin{array}{l}38.41 \\
(14.68)\end{array}$ & $\begin{array}{c}39.5 \\
(12.23)\end{array}$ & $\begin{array}{l}44.72 \\
(17.25)\end{array}$ & $\begin{array}{l}44.75 \\
(16.84)\end{array}$ & $\begin{array}{l}45.22 \\
(12.99)\end{array}$ \\
\hline $\begin{array}{l}\text { Domestic time } \\
\text { per week }\left(h h_{\mathrm{i}}\right) \text {, } \\
\text { hrs }\end{array}$ & $\begin{array}{l}46.87 \\
(29.8)\end{array}$ & $\begin{array}{c}45 \\
(30.7)\end{array}$ & $\begin{array}{l}42.9 \\
(30.4)\end{array}$ & $\begin{array}{l}14.72 \\
(16.47)\end{array}$ & $\begin{array}{l}15.71 \\
(19.36)\end{array}$ & $\begin{array}{l}13.74 \\
(17.52)\end{array}$ \\
\hline $\begin{array}{l}\text { Total working } \\
\text { time per week } \\
\left(H_{\mathrm{i}}\right), \text { hrs }\end{array}$ & $\begin{array}{l}85.66 \\
(31.92)\end{array}$ & $\begin{array}{l}83.23 \\
(31.49)\end{array}$ & $\begin{array}{l}82.36 \\
(31.53)\end{array}$ & $\begin{array}{l}59.39 \\
(22.69)\end{array}$ & $\begin{array}{l}60.43 \\
(24.93)\end{array}$ & $\begin{array}{l}58.95 \\
(22.48)\end{array}$ \\
\hline $\begin{array}{l}\text { Hourly wage } \\
\left(w_{\mathrm{i}}\right), \text { roubles }\end{array}$ & $\begin{array}{l}3.87 \\
(10.9)\end{array}$ & $\begin{array}{l}6.12 \\
(14.5)\end{array}$ & $\begin{array}{c}7 \\
(17)\end{array}$ & $\begin{array}{l}7.8 \\
(45)\end{array}$ & $\begin{array}{c}10.46 \\
(36)\end{array}$ & $\begin{array}{c}12.7 \\
(55.5)\end{array}$ \\
\hline $\begin{array}{l}\text { Household total } \\
\text { monthly income } \\
\text { (Y), roubles }\end{array}$ & $\begin{array}{c}2196 \\
(14484)\end{array}$ & $\begin{array}{l}2696 \\
(5878)\end{array}$ & $\begin{array}{l}2887 \\
(6145)\end{array}$ & $\begin{array}{c}2196 \\
(14484)\end{array}$ & $\begin{array}{l}2696 \\
(5878)\end{array}$ & $\begin{array}{l}2887 \\
(6145)\end{array}$ \\
\hline
\end{tabular}

Source: RLMS. (standard errors in parentheses).

The difference in total working time between men and women is particularly striking: though women work slightly fewer hours in the market (as is the case in many countries), the total amount of domestic work performed by women is substantial, as is the difference between men's and women's total work hours. 


\subsection{Self-reported income and its interpretation}

To measure individual income, we use the following Subjective Economic Ladder question from the RLMS: "Please imagine a 9-step ladder where on the bottom, the first step, stand the poorest people, and on the highest step, the ninth, stand the rich. On which step are you today?" We analyze the intra-family correlation in the answers to this question. Here we make the assumption that household members give the same answer to this question if they receive the same share (one half) of full household income, which includes monetary (market and domestic) as well as non-monetary income.

For the descriptive statistics we include all couples in which individuals both gave answers to the above question and provided wage information. To analyze self-rated income, we collapse the highest ranks $(6,7,8$, and 9$)$ of the ladder into one category: few respondents considered themselves as amongst the richest. Table 3 summarizes the distribution of selfrated economic welfare. The vast majority of individuals feel poor: if we take the poorest two rungs to be the subjectively poor, the subjective poverty rate rose from $19.12 \%$ in 1994 to $23.91 \%$ in 1998 . Most individuals say they are on steps 3, 4 and 5 of the 9-rung ladder.

\section{Table 3. Income Levels.}

\begin{tabular}{lcccc}
\hline Economic Ladder Question & Round 5 (1994) & Round 6(1995) & Round 7 (1996) & Round 8 (1998) \\
1- the poorest; 6 - the richest & Number (\%) & Number (\%) & Number (\%) & Number (\%) \\
\hline 1 & $109(6.0)$ & $145(9.1)$ & $72(6.3)$ & $102(8.1)$ \\
2 & $238(13.1)$ & $184(11.6)$ & $147(12.8)$ & $198(15.8)$ \\
3 & $471(25.9)$ & $350(22.0)$ & $266(23.1)$ & $333(26.5)$
\end{tabular}




\begin{tabular}{lcccc}
\hline 4 & $462(25.4)$ & $403(25.4)$ & $291(25.3)$ & $309(24.6)$ \\
5 & $404(22.3)$ & $386(24.3)$ & $280(24.3)$ & $243(19.4)$ \\
6 & $131(7.2)$ & $121(7.6)$ & $94(8.2)$ & $70(5.6)$ \\
\hline Total (individuals) & $1815(100)$ & $1589(100)$ & $1150(100)$ & $1255(100)$ \\
\hline
\end{tabular}

Source: RLMS (rounds 5-8).

In this paper we are interested in income differences within a given household. Table 4 presents the differences in the Economic Ladder replies of husbands and wives. We consider married household heads, and compare their answer to that of their spouse. In over half of households men and women give different answers to the subjective question, as shown in Table 4 . Almost $18 \%$ of men feel one step poorer than their wives and $10 \%$ differ by more than 2 steps. On average, women report lower incomes than men in the same households: in 1998 , in over $34 \%$ of households the wife reports lower income, versus only $28 \%$ of households in which husbands reported being poorer. Our interpretation of the difference is that, as income sharing is the result of a bargaining process, income is not necessarily equally shared between husband and wife. This assumption is widely discussed and tested below.

\section{Table 4. Within household discrepancies in self-reported income}

\begin{tabular}{lcccc}
\hline Wife's score minus & Round 5 (1994) & Round 6(1995) & Round 7 1996) & Round 8 (1998) \\
Husband's score & Number (\%) & Number (\%) & Number (\%) & Number (\%) \\
\hline-2 & $87(10.8)$ & $61(9.4)$ & $53(11.3)$ & $60(11.8)$ \\
-1 & $139(17.3)$ & $126(19.4)$ & $101(21.6)$ & $112(22.1)$ \\
0 & $339(42.2)$ & $283(43.5)$ & $188(40.3)$ & $192(37.9)$ \\
1 & $142(17.7)$ & $127(19.5)$ & $80(17.1)$ & $95(18.7)$ \\
2 & $97(12.1)$ & $53(8.1)$ & $45(9.6)$ & $48(9.5)$ \\
\hline Total households & $804(100)$ & $650(100)$ & $467(100)$ & $507(100)$ \\
\hline
\end{tabular}


Source: RLMS (rounds 5-8).

0 - there is no difference between husband's and wife's responses. -1 - the wife is situated one step lower than her spouse, -2 -the wife is situated 2 or more steps lower than her spouse. 1- the wife is situated one step higher than her spouse, 2 - the wife is situated 2 or more steps higher than her spouse.

We use these income differences to construct an index of intra-household inequality for the empirical analysis.

\subsection{Are subjective answers reliable?}

We first provide some evidence to support the assumption that subjective data contain useful information. Ravallion and Lokshin (2001, 2002), for example, argue that though "the welfare inferences drawn from answers to subjective survey questions are clouded by concerns about measurement errors and how latent psychological factors influence observed respondent characteristics", subjective measures of income and poverty can be used as complements to standard socio-economic poverty measures. The use of subjective data, launched by the Leyden school in the 1970's for subjective poverty measurement, has developed rapidly since the late 1990's (Senik, 2005). Many nationally-representative household surveys such as the British Household Panel Survey (BHPS), the German SocioEconomic Panel (GSOEP) or the data used in this paper - the Russian Longitudinal Monitoring Survey (RLMS) - contain subjective questions related to general well-being, satisfaction with income, job, health and so on, or individuals' attitudes towards variables such as inequality or unemployment. These questions are generally used as proxies for welfare and well-being. In this reading, individuals themselves define their own level of welfare and provide information that would not be otherwise available, at least in large-scale surveys.

The main justification for the use of subjective data comes from the limitation of the axiom of revealed preferences (Senik, 2005). The traditional approaches to individual 
behavior can be complemented by the use of data on individual perceptions in the cases when use of the former is restricted by the presence of externalities, social interactions, and so on. For example, subjective information is often used to reveal the non-pecuniary costs of unemployment (Clark and Oswald, 1994; Winkelmann and Winkelmann, 1998) and individuals' attitudes towards inequality can help to design redistributive policies $(\mathrm{Ng}, 1996$; Ravallion and Lokshin, 2000). In general, these analyses provide consistent results that agree with our common sense. However, two key assumptions are necessary for the analysis of subjective data: that individuals are able to evaluate their own situation, and that responses can be compared between individuals (Ferrer-i-Carbonell, 2002). The reliability and validity of individual answers have been extensively studied in the recent literature (Diener, 1984; Diener et al., 1999; Veenhoven, 1993), and Easterlin (2001) has pointed out that "the general conclusion of such assessments is that subjective indicators, ..., though not perfect, do reflect respondents' substantive feelings of well-being". Keeping these reflections in mind, we appeal to subjective data in a relatively new sphere: the analysis of intra-household inequality?

A number of critics have worried about the comparison of income scales: people live in different social environments, so their answers about income may merely reflect their position relative to their own social environment rather than to a common scale. The argument is not totally convincing in our context, as we can assume that two individuals living together and sharing, at least partly, their income, have the same scale for selfpositioning on the income ladder. We show below (Table 5) that both spouses have in mind an income including within household transfers when answering the question. Thus, for none of them would the often quoted reference group of work colleagues, for example, be relevant. Instead, here, the relevant reference group would rather be other households they know

\footnotetext{
${ }^{9}$ As far as we know, the only other application of subjective information to intra-household distribution
} of welfare is Bonke and Browning (2003), in which they use a measure of self-perceived economic well-being). 
(which could, of course, include colleagues of both sides). As husbands and wives share a similar social environment, they should thus share the same reference points regarding their income relative to that of other individuals in households that they know. Such reasoning is also supported by the finding of Plug and Van Praag (1998), who report that both adult partners appear to answer almost identically to subjective questions of the Leyden-type

Another issue is that we may define equal sharing too narrowly. We are aware that interpreting small differences in the answers to subjective questions as revealing true inequality in income sharing may imply too high a level of confidence in interpersonal comparisons of subjective answers. We thus allow for some heterogeneity between partners by interpreting a difference of one in replies as indicating no difference in income (one being optimistic, the other one pessimistic, for example, or one being in an especially good mood on the day of the interview).

We construct an index which takes the value of 0 if the within household response difference equals -2 or less (the wife feels poorer than her husband); 1 if the difference between wife's and husband's replies is no greater than 1 in absolute value (the two partners report more or less the same income); and 2 if the wife reports higher economic welfare than her husband (a difference on the scale of at least 2$)^{10}$.

A final objection concerns the question asked in the data: "on which step are you today?". Although this is clearly asked on an individual basis within the individual questionnaire, it does not explicitly refer to household income-sharing. To test whether people, when answering this question, could have in mind their own earnings, rather than their share of household full income, we compute the simple correlations shown in table 5 below.

\footnotetext{
${ }^{10} \mathrm{We}$ also ran the estimations with equal sharing corresponding to strict equality in the answers. The results were very similar.
} 
Table 5. Correlations between wages and household members' replies to the income question

\begin{tabular}{|l|c|c|}
\hline & Woman's reply & Man's reply \\
\hline$w_{f} h_{f}$ & 0.16 & 0.12 \\
\hline$w_{m} h_{m}$ & 0.18 & 0.23 \\
\hline
\end{tabular}

Table 5 shows that household members clearly refer to a kind of household income, i.e. including within household transfers, rather than to their own earnings only when answering the income question. Couples agree that their income is more strongly correlated with the husband's labor earnings (which generally contributes a larger share to total household monetary income), and more weakly correlated with the wife's labor earnings (the wife's monetary contribution being generally lower). Also note that, though a higher correlation is found for both with the husband's earnings, the correlation with one own's contribution to earnings is also found higher for both genders, than that given by the spouse for his/her spouse's earnings. This is consistent with our interpretation in terms of a sharing rule. If a higher labor income increases my bargaining power, then, if my wage increases, I' shall answer a higher value to the income question, for two reasons: first, because of a positive income effect, which exerts the same positive influence upon my spouses' income, and, second, because of a "negotiation effect", which increases my income share, but, conversely, decreases my spouse's. Because of the negotiation effect, a stronger positive correlation is thus expected for each spouse with their own labor income than the correlation with the spouse's labor income found for the opposite gender.

\subsection{A test of the collective model}


Having assumed that the data provide reliable information on the individual shares of full income, $\Phi_{f}$ and $\Phi_{m}$ we can directly test the usual assumptions made regarding the sharing rule.

The empirical model describing intra-household inequality (equation 1.4 above), can be formulated as an endogenous ordered probit, derived from the sharing rule. As the allocation of time is endogenous in this model, introducing household production requires that the profit from household production, $\Pi$, be endogenized. This is carried out here by adding two simultaneous equations of labor supply in domestic production, for husbands and wives. Note that, as the sharing rule itself is generally assumed to be a function of monetary characteristics (wages and non-labor income), but not directly of non-monetary variables, such as household productivity, the theoretical model implies that the only channel between the variables of the ordered probit and the two latter equations is via the profit from domestic production.

The model is estimated by full information maximum likelihood (FIML).

\subsubsection{The econometric model}

Let $I$ be an index function taking values 0,1 or 2 depending on whether the difference observed between female and male levels of income is negative, zero or positive.

$$
\mathrm{I}=\left\{\begin{array}{cc}
0, & \text { if } \Phi_{f}<\Phi_{m} \\
1, & \text { if } \Phi_{f}=\Phi_{m} \\
2, & \text { if } \Phi_{f}>\Phi_{m}
\end{array}\right.
$$

Let $\Phi_{f} *$ be a criterion function associated with an unobservable sharing rule:

$$
\Phi_{f} *=\gamma^{\prime} \mathbf{Z}+\varepsilon,
$$


where $\mathbf{Z}$ is a vector of household-specific characteristics and distribution factors which are assumed to influence the sharing rule. In particular, $\mathbf{Z}$ contains the difference in wages $\left(w_{m}-w_{f}\right)$ and non-labor income $y$. Note that here household exogenous income $y$ can be individualized, which also implies that individual exogenous incomes can be used as distribution factors.

The index function can then be written as:

$$
\mathrm{I}=\left\{\begin{array}{l}
0, \text { if } \Phi_{f} * \leq \kappa_{1}, \\
1, \text { if } \kappa_{1}<\Phi_{f} * \leq \kappa_{2}, \\
2, \text { if } \Phi_{f} *>\kappa_{2},
\end{array}\right.
$$

where $k_{1}$ and $k_{2}$ are unknown parameters to be estimated.

Recall that the sharing rule $\Phi_{f}$ depends on the profit from domestic production $\Pi$, which is endogenous as household production depends on the time devoted to household work and wage rates. As such, system (2.2) needs to be completed by equations describing household work. The resulting system (2.3) is the econometric representation of the theoretical model (1.4):

$$
\begin{aligned}
& \mathrm{I}=\left\{\begin{array}{l}
0, \text { if } \Phi_{f} * \leq \kappa_{1}, \\
1, \text { if } \kappa_{1}<\Phi_{f} * \leq \kappa_{2}, \\
2, \text { if } \Phi_{f} *>\kappa_{2},
\end{array}\right. \\
& \text { and : } \quad \boldsymbol{t}_{f}=\boldsymbol{\alpha}_{f} \boldsymbol{X}_{f}+u_{1} \\
& t_{m}=\boldsymbol{\alpha}_{m} \boldsymbol{X}_{m}+u_{2}
\end{aligned}
$$


where $\boldsymbol{\alpha}_{i}$ are the parameter vectors, $\mathbf{X}_{i}$ are the vectors of individual $i$ specific characteristics and household-specific productivity factors. The error terms $\varepsilon, \mathrm{u}_{1}$ and $\mathrm{u}_{2}$ are assumed to have a trivariate standard normal distribution with zero mean and covariance matrix $\boldsymbol{\Sigma}$ :

$$
\boldsymbol{\Sigma}=\left[\begin{array}{ccc}
1 & \sigma_{\varepsilon u_{1}} & \sigma_{\varepsilon u_{2}} \\
\sigma_{\varepsilon u_{1}} & \sigma_{1}^{2} & \sigma_{u_{1} u_{2}} \\
\sigma_{\varepsilon u_{2}} & \sigma_{u_{1} u_{2}} & \sigma_{2}^{2}
\end{array}\right]
$$

with $\sigma_{\varepsilon_{u_{j}}}=\operatorname{cov}\left(\varepsilon, u_{j}\right), j=1,2, \sigma_{u_{1} u_{2}}=\operatorname{cov}\left(u_{1}, u_{2}\right), \sigma_{1}^{2}=\operatorname{Var}\left(u_{1}\right)$ and $\sigma_{2}^{2}=\operatorname{Var}\left(u_{2}\right)$.

\subsubsection{Maximum Likelihood Estimation}

The model is estimated by full information maximum likelihood (FIML). This estimation method implements the full information ML procedure to estimate simultaneously the ordered and continuous parts of the model in order to provide consistent standard errors.

The likelihood function for the system of equations (2.3) is:

$$
\begin{aligned}
L=\prod_{i: I=0} & {\left.\left[F\left(\left(\kappa_{1}-\gamma_{i}{ }^{\prime} \mathbf{Z}_{i}\right)\right) u_{1 i}, u_{2 i}\right) \times f\left(u_{1 i}, u_{2 i}\right)\right] \times } \\
& \left.\times \prod_{i: I=1}\left[\left(F\left(\left(\kappa_{2}-\gamma_{i}{ }^{\prime} \mathbf{Z}_{i}\right) \mid u_{1}, u_{2}\right)-F\left(\left(\kappa_{1}-\gamma_{i}{ }^{\prime} \mathbf{Z}_{i}\right)\right) \mid u_{1 i}, u_{2 i}\right)\right) \times f\left(u_{1 i}, u_{2 i}\right)\right] \times \\
& \times \prod_{i: I=2}\left[1-F\left(\left(\kappa_{2}-\gamma_{i}{ }^{\prime} \mathbf{Z}_{i}\right) \mid u_{1 i}, u_{2 i}\right) \times f\left(u_{1 i}, u_{2 i}\right)\right]
\end{aligned}
$$

where $i$ denotes the $i$ th observation, and $F\left(. \mid u_{1 i}, u_{2 i}\right)$ is the conditional cumulative distribution function of $\varepsilon$ on $u_{1 i}, u_{2 i} ; f\left(u_{1 i}, u_{2 i}\right)$ is the bivariate standard normal distribution function. 
The variable $\varepsilon \mid u_{1}, u_{2}$ follows a normal distribution. Denoting

$$
\widetilde{\Sigma}=\left[\begin{array}{cc}
\sigma_{1}^{2} & \sigma_{u_{1} u_{2}} \\
\sigma_{u_{1} u_{2}} & \sigma_{2}^{2}
\end{array}\right]
$$

we can calculate its mean $\mu$ and variance $\sigma^{2}$ as follows (Greene, 2000):

$$
\begin{aligned}
& \mu=\left(\sigma_{\varepsilon u_{1}}, \sigma_{\varepsilon u_{2}}\right) \widetilde{\Sigma}^{-1}\left(u_{1}, u_{2}\right)^{\prime}=\left[\left(\rho_{1} u_{1} / \sigma_{1}+\rho_{2} u_{2} / \sigma_{2}\right)-\rho\left(\rho_{1} u_{2} / \sigma_{2}+\rho_{2} u_{1} / \sigma_{1}\right)\right] /\left(1-\rho^{2}\right) \\
& \sigma^{2}=1-\left(\sigma_{\varepsilon u_{1}}, \sigma_{\varepsilon u_{2}}\right) \widetilde{\Sigma}^{-1}\left(\sigma_{\varepsilon u_{1}}, \sigma_{\varepsilon u_{2}}\right)^{\prime}=1-\left[\rho_{1}^{2}+\rho_{2}^{2}-2 \rho \rho_{1} \rho_{2}\right] /\left(1-\rho^{2}\right),
\end{aligned}
$$

where $\rho_{1}, \rho_{2}$, and $\rho$ are the coefficients of correlation between $\varepsilon$ and $u_{1}, \varepsilon$ and $u_{2}$, and $u_{1}$ and $u_{2}$ respectively.

The log of the likelihood function can be defined in terms of the cumulative standard normal distribution as below:

$$
\begin{gathered}
\ln L=\sum_{i: I=0} \ln F_{0}\left(z_{i}^{1}\right) \times f\left(u_{1 i}, u_{2 i}\right)+\sum_{i: I=1} \ln \left(F_{0}\left(z_{i}^{2}\right)-F_{0}\left(z_{i}^{1}\right)\right) \times f\left(u_{1 i}, u_{2 i}\right)+ \\
+\sum_{i: I=0} \ln \left(1-F_{0}\left(z_{i}^{2}\right)\right) \times f\left(u_{1 i}, u_{2 i}\right)
\end{gathered}
$$

with $F_{0}$ standing for the cumulative standard normal distribution function and $z_{i}^{j}=\left(k_{j}-\gamma_{i}{ }^{\prime} \mathbf{Z}_{i}-\mu\right) / \sigma,(j=1,2)$

\subsubsection{The results}

The dependent variables are the natural logarithms of male and female monthly domestic labor supply in hours, and the index of intra-household inequality. All of the independent variables are here assumed to be exogenous. We include the wage rates of both husband and wife, individual demographic characteristics (age, age-squared and education), 
household characteristics (number of children, assets and possession of durables) and type and region of settlement. The estimates are reported in Table 6 below.

Relatively few variables are significantly correlated with domestic labor supply. The partner's wage rate is an important determinant of women's domestic working time: higher male wages are associated with greater domestic labor supply by the wife, while higher female wages have no significant effect on males' domestic work. Other significant variables in both equations are the number of young children (0-7 years old) and older children (7-18 years old) in the household: as expected, more children increase both spouses' domestic work especially when the children are younger. Non labor-market variables are not significant here. Living space, durables possession or owning an individual plot do not influence the hours of domestic work of either husband or wife. Household work does vary by region and type of settlement. Both partners work less in Moscow and St-Petersburg, and in the Urals and Eastern and Western Siberia women's domestic labor supply is lower than in the other regions. As might be expected, both men and women living in rural areas work more at home than do those living in urban areas.

We have included in the ordered probit equation variables, such as non-labor income $^{11}$, which we may expect to be correlated with the spouses' bargaining power. As noted above, this index takes a value of 0 if the within household difference in replies is less than or equal to -2 (the wife feels poorer than her husband); 1 if this difference is no greater than 1 in absolute value (the two partners thus giving more or less the same answer to the income question); and 2 if the wife reports a higher level of income than her husband (with the difference on the scale being at least 2). The wage difference in these equations is expressed as the natural logarithm of the difference between female and male wages.

\footnotetext{
${ }^{11}$ For each household, the data give information upon the different sources of income. Household non-labor income is obtained as the sum of all the different types of non-labor income.
} 


\section{Table 6. ML Estimation of Woman and Man's Domestic Labor Supply and the Index of Intra-Household Inequalitya .}

\begin{tabular}{|c|c|c|c|c|c|c|}
\hline & \multirow{2}{*}{$\begin{array}{c}\text { Woman's } \\
\text { domestic } \\
\text { labor supply } \\
\text { Coefficient }\end{array}$} & \multirow{2}{*}{$\begin{array}{c}\text { Man's } \\
\text { domestic } \\
\text { labor supply } \\
\text { Coefficient }\end{array}$} & \multirow{2}{*}{$\begin{array}{c}\text { Index }^{\mathrm{a}} \\
\text { Coefficient }\end{array}$} & \multicolumn{3}{|c|}{ Marginal effects for the ordered probit } \\
\hline & & & & $\mathrm{dP}(0) / \mathrm{dX} 3$ & $\mathrm{dP}(1) / \mathrm{dX} 3$ & $\mathrm{dP}(2) / \mathrm{dX} 3$ \\
\hline Ln of man's wage rate & $0.044 * * *$ & 0.014 & $0.1 * * *$ & 0.0007 & -0.00004 & -0.0006 \\
\hline Ln of woman's wage rate & -0.006 & 0.015 & & -0.002 & 0.00011 & 0.002 \\
\hline Wage difference ${ }^{\mathrm{b}}$ & & & $0.17 * * *$ & -0.022 & 0.0014 & 0.021 \\
\hline Man's age & & -0.014 & & & & \\
\hline Man's age squared & & 0.014 & & & & \\
\hline Woman's age & $0.025 * *$ & & & & & \\
\hline Woman's age squared & $-0.026 * * *$ & & & & & \\
\hline Age difference ${ }^{c^{1}}$ & & & $-0.013 * *$ & 0.002 & -0.0001 & -0.002 \\
\hline Woman has technical or higher education & -0.032 & & & & & \\
\hline Man has technical or higher education & & 0.054 & & & & \\
\hline Male education (years) & & & -0.01 & 0.00004 & -0.000003 & -0.00003 \\
\hline Woman has higher degree of education than man & & & 0.06 & -0.015 & 0.03 & -0.015 \\
\hline Household non-labor income & & & -0.0002 & -0.003 & -0.0002 & 0.003 \\
\hline Number of children 0-7 years old & $0.44 * * *$ & $0.455 * * *$ & 0.017 & -0.011 & -0.0007 & 0.01 \\
\hline Number of children $7-18$ years old & $0.19 * * *$ & $0.171 * * *$ & $0.06 *$ & -0.014 & 0.0008 & 0.013 \\
\hline Number of elderly persons in the household & 0.021 & $0.121 * *$ & 0.08 & 0.007 & 0.0004 & -0.006 \\
\hline Ln of living space (sq. meters) & -0.020 & -0.063 & -0.04 & 0.004 & -0.0002 & -0.003 \\
\hline Automobile owned & 0.024 & -0.053 & & & & \\
\hline Washing machine owned & -0.030 & 0.003 & & & & \\
\hline Family is working on an individual plot & 0.016 & 0.015 & -0.02 & 0.004 & -0.009 & 0.004 \\
\hline Rural & $0.146 * *$ & $0.22 * * *$ & & & & \\
\hline North Caucasian & -0.030 & 0.03 & & & & \\
\hline Volga-Vaytski and Volga Basin & -0.034 & 0.010 & & & & \\
\hline Moscow - St-Petersburg & $-0.09 *$ & $-0.16 * *$ & -0.02 & -0.004 & -0.008 & 0.004 \\
\hline Northern and North Western & -0.072 & 0.135 & & & & \\
\hline The Urals & $-0.184 * *$ & -0.06 & & & & \\
\hline Western Siberia & $-0.108^{*}$ & 0.01 & & & & \\
\hline Eastern Siberia and Far Eastern & $-0.15 * * *$ & 0.034 & & & & \\
\hline Round 5 & $0.075 *$ & $0.162 * *$ & 0.09 & -0.02 & 0.04 & -0.02 \\
\hline Round 6 & 0.006 & 0.019 & 0.044 & -0.01 & 0.02 & -0.01 \\
\hline Round 8 & -0.06 & -0.062 & 0.025 & -0.006 & 0.011 & -0.006 \\
\hline Constant & $4.21 * * *$ & $3.82 * * *$ & & & & \\
\hline Ancillary parameters & & & & & & \\
\hline$k_{1}$ & & & $-1.2 * * *$ & & & \\
\hline$k_{2}$ & & & $1.34 * * *$ & & & \\
\hline $\begin{array}{l}\rho_{1} \text { (correlation between woman's domestic labor } \\
\text { supply and the sharing rule) }\end{array}$ & & $-0.06^{*}$ & & & & \\
\hline $\begin{array}{l}\rho_{2} \text { (correlation between man's domestic labor } \\
\text { supply and the sharing rule) }\end{array}$ & & -0.03 & & & & \\
\hline$\rho$ (correlation between man's and woman's supply) & & $0.27 * * *$ & & & & \\
\hline & & $0.615 * * *$ & & & & \\
\hline$\sigma_{2}$ & & $0.985 * * *$ & & & & \\
\hline Number of observations & & 1916 & & & & \\
\hline Log likelihood & & -6462.59 & & & & \\
\hline $\begin{array}{l}\text { * significant at the } 10 \% \text { level; ** signific } \\
\text { a The dependent variable is the index of it } \\
\text { poorer than her husband; } 1 \text { - there is no d } \\
{ }^{b} \text { Wage difference: the difference betweer } \\
{ }^{c} \text { Age difference: the difference between } \\
\text { The reference categories are: Urban ve } \\
\text { Source: RLMS (rounds 5-8) }\end{array}$ & $\begin{array}{l}\text { at the } 5 \% \text { leve } \\
\text { household in } \\
\text { rence, } 2 \text { - the } \\
\text { of woman's re } \\
\text { nan's age and } \\
\text { Rural, Centr: }\end{array}$ & $\begin{array}{l}* * \text { significant } \\
\text { lality: } 0-\text { the } \\
\text { fe reports bein } \\
\text { wage rate and } \\
\text { in's age } \\
\text { and Central Bla }\end{array}$ & $\begin{array}{l}\text { the } 1 \% \text { lev } \\
\text { e reports be } \\
\text { richer than } 1 \\
\text { of man's re } \\
\text {-Earth for } 1\end{array}$ & $\begin{array}{l}\text { husband. } \\
\text { wage rate. } \\
\text { on, Round }\end{array}$ & vave. & \\
\hline
\end{tabular}


The results in Table 6 are in line with those predicted by the theory: the wage difference is highly significant with the "correct" sign.

We thus find, as expected, that the higher is the woman's wage compared to her husband's, the greater is the probability that the woman's response to the income question is higher than her husband's. This conclusion is confirmed by the marginal effects analysis in the right-hand panel of Table 6 . The marginal effects are almost the same in absolute value for the first and third categories of the dependent variable, so the result is symmetric. The wage ratio is therefore a powerful determinant of the outcome of intra-household bargaining. Another variable which influences the distribution of full income among household members is the age difference, here the wife's age minus her husband's age. The estimated coefficient on this variable is negative and significant: the older the woman is relative to her husband, the lower the probability of the woman's higher response. The effect of the age difference can be interpreted as showing the greater bargaining power of women who are relatively younger compared to their husband. On the other hand, we find no significant effect of the difference in partners' education levels on the distribution of income within the household.

These results are in accordance with the collective model predictions and strongly support the assumption made throughout the paper that the answers given to the income question do correspond to individual income shares, which themselves are the result of a bargaining process. Note that in the case of the unitary model of household behaviour, the total individual income of each partner would be the same and the discrepancies in self reported levels would be random and thus not related to the wages or to age differences as it is found here.

The correlations between domestic labor supplies and the sharing rule are low (see Table A1 in the Appendix for the values of $\rho_{1}$ and $\rho_{2}$ ). This result provides some support for our further assumption that the surplus from domestic production (profit $\Pi$ in the theoretical 
model) is negligible compared to other sources of household income. This is equivalent to assuming that household production is evaluated at its market price, i.e. using the level of wages.

The results of our estimation show that the wage and age differentials are important determinants of intra-household inequality. These results support the choice of the collective model to analyze the intra-household allocation of income.

We now turn to the second main objective of the paper, namely the identification of the sharing rule.

\section{IDENTIFYING THE SHARING RULE: A NEW METHOD}

Rapoport, Sofer and Solaz (2003) show that, if the allocations of household members' time between domestic work, market work and leisure are observable, and if there exists at least one observable distribution factor, then the sharing rule can be recovered up to a constant

Here, additional information on the income levels of household members provides us with a supplementary constraint allowing to completely identifying the sharing rule.

The derivatives of the sharing rule can be computed using the estimated parameters of the simultaneous estimation of total labor supply (market plus domestic work):

$$
\begin{aligned}
& H_{f}=\boldsymbol{\beta} \boldsymbol{Q}+v_{1} \\
& H_{m}=\boldsymbol{\beta}_{m} \mathbf{Q}+v_{2}
\end{aligned}
$$

with $H_{i}=h_{i}+t_{i}, i=f, m$ 
where $\boldsymbol{\beta}_{i}$ are the parameter vectors, $\mathbf{Q}=\left(w_{f}, w_{m}, y_{f}, y_{m}, \mathbf{s}, \mathbf{z}\right)$ is a vector whose components are the individuals' specific characteristics and household-specific distribution factors, and $v_{1}$ and $v_{2}$ are distributed bivariate normally. We call this result $\mathrm{R} 1$

The next step is to identify the constant of the sharing rule, as well as its derivatives ${ }^{12}$. To do this, assume that $\Pi$ is observable (which is not the case), $\Phi_{f}\left(w_{f}, w_{m}, y_{f}, y_{m}, \mathbf{s}, \mathbf{z}\right)$ can be recovered from the sample of households who share full income (approximately) equally. For this sample, we have:

$$
\Phi_{f}=\Phi_{m}=\frac{1}{2}\left[\left(w_{m}+w_{f}\right) T+y+\Pi\right]
$$

Unfortunately, $\Pi$ never can be observed. We thus assume in addition that, empirically, the surplus from domestic production is negligible compared to other sources of household income. This is equivalent to assuming that household production is evaluated at its market costs, i.e. wages.

The empirical justification for this assumption is the low values found for the correlations between domestic labor supply and the sharing rule equations $\left(\rho_{1}\right.$ and $\rho_{2}$ in equations (2.3) above). The correlation between men's hours of domestic work and the index of intra-household inequality is negative, small (-0.03) and insignificant. For women, the correlation is also small, negative $(-0.06)$ but significant at the $10 \%$ level. As, for households where both members participate in the labor market, $\Pi$ is the only channel in the theoretical model through which domestic work and the sharing rule could be correlated, these findings support the assumption that we make above.

Here, we propose a direct identification method, based on the additional condition provided by the index of intra-household equality. For this, we use a two-stage estimation.

\footnotetext{
${ }^{12}$ Note that Rapoport, Solaz and Sofer, 2005, gives a method for estimating the derivatives of the sharing rule when a significant distribution factor exists.
} 


\subsection{A Two-stage estimation approach}

In theory, the estimation of the total labor supplies of the two household members on the sub-sample of the couples for whom full income shares are fully "observed" should allow us to identify the individual shares of full income for the rest of the sample. One problem, we face, though, is that of over-identification: the estimates of individual full income shares should sum up to the (observed) full income, which is generally not the case. We thus chose the strategy of estimating rather the ratio of full income shares. We use three equations:

$$
\left\{\begin{array}{l}
H_{f}=\alpha_{f}+\beta_{f} \ln \Phi_{f}+\gamma_{f} \mathbf{X}_{f}+e_{f} \\
H_{m}=\alpha_{m}+\beta_{m} \ln \Phi_{m}+\gamma_{m} \mathbf{X}_{m}+e_{m}
\end{array}\right.
$$

and

$$
\ln \left(\frac{\Phi_{m}}{\Phi_{f}}\right)=\boldsymbol{\delta} \mathbf{X}+\lambda
$$

where $\left(\alpha_{f}, \alpha_{m}, \beta_{f}, \beta_{m}\right), \boldsymbol{\gamma}_{f}, \boldsymbol{\gamma}_{m}, \boldsymbol{\delta}$ are the parameter vectors; $\mathbf{X}_{\mathrm{f}}$ and $\mathbf{X}_{\mathrm{m}}$ are respectively the vectors of female and male individual characteristics; $\mathbf{X}=\left(w_{f}, w_{m}, y_{f}, y_{m}, \mathbf{s}, \mathbf{z}\right) ; e_{f}, e_{m}$ and $\lambda$ are the error terms which are assumed to have a joint normal distribution with zero means. To this we add the budget constraint: $\Phi=\Phi_{f}+\Phi_{m}=\left(w_{f}+w_{m}\right) T+y$

Using the sub-sample $S_{l}$ of households who are assumed to share full income equally, i.e. here the sub-sample of couples for whom the index value calculated above is 1 (the same answer, plus or minus one, to the subjective ladder question), we obtain:

$$
\Phi_{f}=\Phi_{m}=\frac{1}{2}\left[\left(w_{m}+w_{f}\right) T+y+\Pi\right]
$$


Or, assuming $\Pi$ to be only small,

$$
\Phi_{f}=\Phi_{m}=\frac{1}{2}\left[\left(w_{m}+w_{f}\right) T+y\right]
$$

The system (3.6) can then be estimated using this sub-sample.

In this first stage the vectors of parameters $\left(\alpha_{f}, \alpha_{m}, \beta_{f}, \beta_{m}\right), \gamma_{f}, \gamma_{m}$ can be identified.

Note that the probability mass corresponding to the index value of 1 is continuously spread over the interval $\left\lfloor\Phi_{f}^{*}-k_{1} ; \Phi_{f}^{*}-k_{2}\right\rfloor$ rather than being concentrated at the point $\Phi_{f}=\Phi_{m}=1 / 2\left\lfloor\left(w_{m}+w_{f}\right) T+y\right\rfloor$. Thus for those individuals belonging to the sub-sample $S_{1}$ the hypothesized equality between partners' full incomes holds only approximately: we have made this choice (see section 2 above) in order to make our formal definition of equality at the same time less restrictive and more realistic. According to our interpretation, our measures of $\Phi_{f}$ and $\Phi_{m}$ as $1 / 2\left\lfloor\left(w_{m}+w_{f}\right) T+y\right\rfloor$ are subject to error, implying that the estimators are biased towards zero (Greene, 2000). This bias can be corrected by using the results obtained from the ordered probit model. ${ }^{13}$

Another source of bias is sample selection when we use the sub-sample of couples for whom the index value is 1 . We correct for this selection bias by using the results from the ordered probit model. The method and demonstration are contained in Appendix A.

The vector of parameters $\boldsymbol{\delta}$ is identified in the second stage by estimating (3.7) and using the whole sample of households.

$$
\ln \hat{R}=\boldsymbol{\delta} \mathbf{X}+i
$$

where $\ln \hat{R}$ is the predicted logarithm of the ratio between the man's and the woman's shares:

\footnotetext{
${ }^{13}$ The proof is available from the authors.
} 


$$
\ln \hat{R}=\left(H_{m}-\alpha_{m}-\gamma_{m} \mathbf{X}_{m}\right) \cdot \beta_{m}-\left(H_{f}-\alpha_{f}-\gamma_{f} \mathbf{X}_{f}\right) \cdot \beta_{f}
$$

and the error term $i$ follows a normal distribution with zero mean:

$$
i=\lambda+e_{m} / \beta_{m}-e_{f} / \beta_{f}
$$

Finally the shares $\Phi_{f}$ and $\Phi_{m}$ are calculated using the predicted sharing ratio $\hat{R}=\frac{\Phi_{m}}{\Phi_{f}}$ and their sum equalized to (observed) full income: $\Phi=\Phi_{f}+\Phi_{m}=\left(w_{f}+w_{m}\right) T+y$.

Due to the poor quality of our measure of non-labor income, which cannot be individualized correctly in the RLMS data, the latter strategy is followed in the empirical analysis. The method of estimation is 3SLS in the first stage and OLS in the second stage.

\subsection{The estimation results}

\subsubsection{Labor Supply Estimations}

The explanatory variables used in the total labor supply estimations (market plus domestic work) are the natural logarithm of the individual's full income calculated using (3.8), individual characteristics (age, age squared, number of years of education), household characteristics (number of children, presence of elderly persons, possession of durables such as a car, a washing machine etc.), and type and region of housing.

The dependent variable in the sharing rule equation is the predicted ratio between the male and female shares of full income, $\hat{R}$. The vector of explanatory variables includes the natural logarithms of the wage rates and their squares, and the same individual and household characteristics as in section 2. The estimates are reported in Table B (Appendix B). 
The main results are as follows. The total labor supply of both household members is positively correlated with their individual full incomes and is negatively correlated with their wage rates. This implies a negative relationship between (true) leisure and wages, which, in turn, can be interpreted as incomes being so low that leisure is a very expensive good: the substitution effect dominates the income effect.

\subsubsection{Restrictions on the Slutsky Matrix}

The Slutsky condition for the labor supply model implies that the wage response of the compensated supply of labor is non-negative:

$$
\frac{\partial H_{i}^{c}}{\partial w_{i}} \geq 0
$$

or

$$
w_{i} \frac{\partial H_{i}}{\partial \ln w_{i}}+\Phi_{i}\left(T-H_{i}\right) \frac{\partial H_{i}}{\partial \ln \Phi_{i}} \geq 0
$$

Given the outcomes of the coefficients estimates in Table C (Appendix C), the latter condition is satisfied for both female and male labor supply for the whole sample of observations as well as at the mean wages, labor supply and full incomes.

\subsubsection{Sharing Rule Estimation}

Due to the nonlinearity of the estimated equation in terms of wages, the elasticity of the dependent variable with respect to wages is defined by both a constant term and a term 
which depends on the corresponding wage ${ }^{14}$. The constant term of the sharing ratio elasticity with respect to wages is in each case large and significant: -2.93 for women's wages and 1.65 for men's. That is, the direct effect of women's wages on the sharing ratio is negative, so that the effect of women's wages on the woman's share is positive, and negative on the men's share. Symmetrically, the direct effect of men's wages on the sharing ratio is positive, so that the effect of male wages on the woman's share is negative, and the effect on the man's share is positive. The direct effect of women's wages is stronger than that of men's wages. This finding is consistent with the presence of intra-household bargaining. The elasticities of the sharing ratio with respect to both wages calculated at their mean level, are given in Table 7. This table also includes the effect of non-labor income and various household characteristics, allowing us to compare the size of the effect of the different variables on income sharing. $R$ refers to the sharing ratio of full income: $R=\Phi_{m} / \Phi_{f}$

The effect of non-labor income is small and insignificant. However, this result is not totally convincing due to the poor quality of the non-labor income variable. The sharing ratio increases with the man's education and is sharply lower if the woman's level of education is higher than her husband's (although then the latter effect is not significant). Hence, differences in education have a large impact on full-income sharing in the household. The number of children and of elderly people has a negative impact on this ratio, and hence exerts a positive effect on the woman's share but these effects are not significant.

\section{Table 7. Marginal Effects of Wage Rates and other Explanatory Variables on the Sharing Rule (R).}

\footnotetext{
${ }_{14} \frac{\partial \ln R}{\partial \ln w_{i}}=k_{1}+k_{2} \ln w_{i}, i=f, m$; where $k_{1}$ and $k_{2}$ are the regression coefficients on the linear and squared terms respectively.
} 


\begin{tabular}{|c|c|}
\hline & Marginal Effect (in roubles) \\
\hline$\partial \ln R / \partial \ln w_{f}$ & $-0.33^{* * *}$ \\
\hline$\partial \ln R / \partial \ln w_{m}$ & $-0.13^{* * *}$ \\
\hline$\partial R / \partial w_{f}$ & $-0.2^{* * *}$ \\
\hline$\partial R / \partial w_{m}$ & $-0.005^{* * *}$ \\
\hline$\partial R y$ & 0 \\
\hline$\partial R / \partial($ Man's age) & -0.01 \\
\hline$\partial R \partial$ (Age $f-$ Age $m$ ) & 0.02 \\
\hline$\partial R / \partial($ Years of man's education) & $0.3 * * *$ \\
\hline$\partial R / \partial$ (Woman has higher degree) & -0.6 \\
\hline$\partial R / \partial$ (Number of children 0-7 years old) & -0.18 \\
\hline$\partial R / \partial$ ( Number of children 7-18 years old) & -0.13 \\
\hline$\partial R / \partial($ Number of elderly persons in the household) & -0.52 \\
\hline
\end{tabular}

* significant at the $10 \%$ level; ** significant at the $5 \%$ level; *** significant at the $1 \%$ level.

The elasticity as well as the marginal effects of wages show that, at mean wages, the sharing ratio falls when the wages of both household members increases. The effect is much stronger, though, for women's wages than for men's. That is, a raise in any wage benefits women more than it does men. However, this effect is much stronger in the case of an increase in the woman's own wages than for an increase in male wages.

\subsubsection{Simulating the sharing rule}

The results above can be summarized by a numerical example. Consider an average Russian household, represented by a 39-year old woman earning 8 roubles per hour, whose husband is 41 years old earning 13 roubles per hour. Assume that they have a 7-year old child (or older), that both received 13 years of education, that the family lives in a city in the Urals, and that the wave chosen for this exercise is round 7. The variables used in these calculations for the shares and transfers refer to monthly incomes. 
The model yields an estimated probability of $79 \%$ that husband and wife report equality in the sharing of income as measured by our index, I, with the full incomes of the household members amounting to 10920 roubles for the woman and 13156 for the man.

Now assume that woman's wages are the same as her husband's. The probability that the wife receives a lower share decreases to $10 \%$ and predicted income sharing approaches equality, with a ratio between shares of 1.06 .

A one rouble increase in the woman's wage rate leads to a slightly less unequal sharing of household full income, with 11344 roubles allocated to the wife and 13404 allocated to the husband. A one rouble increase in the man's wage rate leads to equal sharing of the extra income (about 335 roubles for each partner) with consequently a slightly less unequal sharing of full income (11258 for the woman and 13490 for the man).

Assume now that the family has another child, aged between 7 and 18, then the probability of the wife receiving a larger share increases to $10.4 \%$ and full income would be reallocated with about 1000 roubles passing from husband to wife. The same reallocation is predicted if the second child is younger or is replaced by an elderly person. Therefore, the presence of children and of elderly persons increases the woman's bargaining power.

The wife's education being higher than her husband's (for example higher education versus technical studies) has a strong effect on the sharing of full income, with the woman now receiving $60 \%$.

The impacts of these various changes on the sharing rule are summarized in Table 8 below.

Table 8. Predicted Impact of Various Changes in the Covariates on the Probability of Equal Full Income Sharing and on the Shares of the Two Partners

\begin{tabular}{|l|c|c|c|c|c|c|c|c|}
\hline & $\begin{array}{c}\mathbf{P 0} \\
\mathbf{( \% )}\end{array}$ & $\begin{array}{c}\mathbf{P 1} \\
\mathbf{( \% )}\end{array}$ & $\begin{array}{c}\mathbf{P 2} \\
\mathbf{( \% )}\end{array}$ & $\boldsymbol{\Phi}_{\mathbf{f}}$ & $\boldsymbol{\Phi}_{\mathbf{m}}$ & $\mathbf{R}$ & $\Delta \boldsymbol{\Phi}_{\mathbf{f}}$ & $\Delta \boldsymbol{\Phi}_{\mathbf{m}}$ \\
\hline Control & 11 & 79 & 10 & 10920 & 13156 & 1.2 & & \\
\hline
\end{tabular}




\begin{tabular}{|l|c|c|c|c|c|c|c|c|}
\hline$\Delta \boldsymbol{w}_{\mathbf{f}}=\mathbf{1}$ rouble & & & & 11344 & 13404 & 1.18 & 424 & 247 \\
\hline$\Delta \boldsymbol{w}_{\mathbf{m}}=\mathbf{1}$ rouble & & & & 11258 & 13490 & 1.198 & 337 & 334 \\
\hline$\Delta \boldsymbol{w}_{\mathbf{f}}=\boldsymbol{w}_{\mathbf{f}}-\boldsymbol{w}_{\mathbf{m}}$ & 10 & 79 & 11 & 13608 & 14499 & 1.06 & 2688 & 1343 \\
\hline $\begin{array}{l}\text { A second } \\
\text { younger child }\end{array}$ & 10 & 79 & 11 & 11623 & 12453 & 1.07 & 703 & -703 \\
\hline $\begin{array}{l}\text { A second older } \\
\text { child }\end{array}$ & 9.6 & 79 & 11.4 & 11887 & 12189 & 1.03 & 967 & -967 \\
\hline $\begin{array}{l}\text { An elderly } \\
\text { person }\end{array}$ & 12 & 79 & 9 & 12063 & 12012 & 1 & 1143 & -1143 \\
\hline $\begin{array}{l}\text { Woman's } \\
\text { higher degree }\end{array}$ & 9.5 & 82 & 8.5 & 15097 & 8978 & 0.6 & 4177 & -4177 \\
\hline
\end{tabular}

P0: Probability of the index taking a value of 0 (wife reports being poorer)

P1: Probability of the index taking a value of 1 (equality)

P2: Probability of the index taking a value of 2 (wife reports being richer)

$\Delta \boldsymbol{\Phi}_{f}$. Change in woman's share.

$\Delta \boldsymbol{\Phi}_{m}$ : Change in man's share.

$\Delta w_{f}$. Woman's wage rate change with respect to the control value

$\Delta w_{m}$ : Man's wage rate change with respect to the control value

\section{CONCLUDING REMARKS}

In this paper we have proposed an application of the collective model to the analysis of intra-household inequality using self-reported income scales. We use a collective model taking into account household production. The results support the assumptions of the collective model. The wage difference within the household is found to be a strong determinant of the intra-household sharing of resources.

We then set out a new method of identification of the sharing rule. Using the results obtained from couples who report the same level of income, and interpreting this as equal income-sharing, we are able to identify the sharing rule for the whole sample. The results are consistent with those predicted by the model: as expected, wages and education level exert a strong influence on the sharing rule, with an increase in female wages increasing women's share more strongly than does an increase in male wages. Perhaps more unexpected is the positive effect of children and of elderly persons on the wife's share. This seems to indicate that variables other than those related to market wages or non-labor income can influence 
intra-household bargaining. Exploring this result further should be the aim of future research, from both an empirical as well as a theoretical point of view.

\section{REFERENCES}

APPS, PATRICIA F., and REES, RAY (1997) "Collective Labor Supply and Household Production", Journal of Political Economy, 105, pp. 178-190.

BONKE, J. AND BROWNING, M. (2003), "The distribution of well-being and income within the household", University of Copenhagen. Department of Economics, Centre for Applied Microeconometrics Working Paper n 2003-01.

BOURGUIGNON, F. and CHIURI, M.C. (2005), "Labor Market Time and Home Production: a new test for collective models of intra-household allocation", CSEF Working Paper 131.

BROWNING, M. and CHIAPPORI, P-A. (1998) "Efficient Intra-Household Allocations: A General Characterization and Empirical Tests", Econometrica, 66, pp. 1241-1278.

BROWNING, M., CHIAPPORI, P-A. and LEWBEL, A. (2004) "Estimating Consumption Economies of Scale, Adult Equivalence Scales, and Household Bargaining Power", mimeo.

CHIAPPORI, PIERRE-ANDRÉ (1998) "Rational Household Labor Supply", Econometrica, 56, pp. 63-89.

CHIAPPORI, PIERRE-ANDRÉ (1992) "Collective Labor Supply and Welfare", Journal of Political Economy, 100, pp. 437-467.

CHIAPPORI, PIERRE-ANDRÉ (1997) "Introducing Household Production in Collective Models of Labor Supply", Journal of Political Economy, 105, pp. 191-209.

CHIAPPORI, P-A., FORTIN, B. and LACROIX, G. (2002) "Marriage Market, Divorce Legislation and Household Labor Supply", Journal of Political Economy, 110, pp.37-72. 
CLARK, A.E., and OSWALD, A.J. (1994). "Unhappiness and Unemployment". Economic Journal, 104, 648-659.

DIENER, E. (1984) "Subjective wellbeing". Psychological Bulletin, 93, pp. 542-575;

DIENER, E., E.M. SUH, R.E. LUCAS and H.L. SMITH (1999) "Subjective wellbeing: Three decades of progress", Psychological Bulletin, 125, pp. 276-302;

EASTERLIN, R.A. (2001) "Income and Happiness: Towards a Unified Theory", Economic Journal, 111(July), pp.465-484;

FERRER-I-CARBONELL, A. "Subjective Questions to Measure Welfare and Well-being", Tinbergen Institute Discussion Paper, 2002-020/3.

FERRER-I-CARBONELL, A. and FRIJTERS, P. (2004) "How important is methodology for the Estimates of the determinants of happiness?", Economic Journal, July, pp. 641-659.

GREENE, W. H.(2000), Econometric Analysis, Fourth Edn., Englewood Cliffs, Prentice-Hall. NG, Y-K. (1996) "Happiness surveys: Some comparability issues and an exploratory survey based on just perceivable increments", Social Indicators Research, 38(1), pp.1-27;

PLUG, E.J.S., VAN PRAAG, B.M.S. (1998), "Similarity in response behavior between household members: An application to income evaluation". Journal of Economic Psychology, 19, 497- 513

RAPOPORT, B., SOFER, C., and SOLAZ, A. (2003), "Household Production in a Collective Model: Some New Results", TEAM Working Paper, Université Paris 1-PanthéonSorbonne.

RAPOPORT, B., SOFER, C., and SOLAZ, A. (2005), "La production domestique dans les modèles collectives", Actualité Economique, forthcoming;

RAVALLION, M. and LOKSHIN, M. (2000) "Who wants to redistribute? The tunnel effect in 1990s Russia", Journal of Public Economics, 76, pp.87-104 
RAVALLION, M. and LOKSHIN, M. (2001) "Identifying Welfare Effects from Subjective Questions", Economica, N68, pp. 335-357.

RAVALLION, M. and LOKSHIN, M. (2002) "Self-Rated Economic Welfare in Russia", European Economic Review, N46, pp. 1453-1473.

SENIK, C. (2004) "When Information Dominates Comparison. Learning from Russian Subjective Panel Data", Journal of Public Economics, 88, p. 2099-2133.

SENIK, C. (2005) "What Can we Learn from Subjective Data? The Case of Income and WellBeing", Journal of Economic Surveys, 19 (1), pp. 43-63.

VEENHOVEN, R. (1993). Happiness in Nations, Subjective Appreciation of Life in 56 Nations 1946-1992. Rotterdam: Erasmus University.

WINKELMANN, L. and WINKELMANN, R. (1998) "Why are the Unemployed So Unhappy? Evidence from Panel Data", Economica, 65, pp. 1-15.

\section{APPENDIX A}

The correction term Ratiol of the selection bias in the labor supply equations is constructed as follows:

$$
E\left(e_{i} \mid I=1\right)=E\left(E\left(e_{i} \mid \varepsilon\right) \mid I=1\right)=M_{1}\left(\sigma_{e_{i} \varepsilon}\right) E(\varepsilon \mid I=1),
$$

where $M_{2}\left(\sigma_{e_{i} \varepsilon}\right)$ is a coefficient depending on the covariance between $\varepsilon$ and $e_{i}$ to be estimated, $i=1,2$.

$$
\text { Ratio1 }=E(\varepsilon \mid I=1)=E\left(\varepsilon \mid z^{1}<\varepsilon<z^{2}\right)=\frac{f\left(z^{1}\right)-f\left(z^{2}\right)}{F\left(z^{2}\right)-F\left(z^{1}\right)},
$$

where $f(),. F($.$) are the standard normal density and cumulative density functions respectively.$ 


\section{APPENDIX B}

\section{Table B. 3SLS Estimation of Woman's and Man's Total Labor Supply and Sharing}

Ratio.

\begin{tabular}{|c|c|c|c|}
\hline & $\begin{array}{l}\text { Woman's Total } \\
\text { Labor Supply }\end{array}$ & $\begin{array}{c}\text { Man's Total } \\
\text { Labor Supply }\end{array}$ & $\begin{array}{c}\text { Ln of Sharing } \\
\text { Ratio } \\
\end{array}$ \\
\hline & Coefficient & Coefficient & Coefficient \\
\hline Ln of individual full income $\left(\Phi_{\mathrm{f}}=\Phi_{\mathrm{m}}\right)$ & $10.2^{*}$ & $9.75^{*}$ & \\
\hline Ln of woman's wage rate & $-23.7 * * *$ & & $-2.93 * * *$ \\
\hline Ln of man's wage rate & & $-27 * * *$ & $1.65^{* * *}$ \\
\hline Ln of woman's wage rate squared & & & $0.58 * * *$ \\
\hline Ln of man's wage rate squared & & & $-0.36 * * *$ \\
\hline Non-labor income & & & -0.005 \\
\hline Woman's age & 3.4 & & \\
\hline Woman's age squared & -3.75 & & \\
\hline Man's age & & $3.15^{*}$ & -0.01 \\
\hline Man's age squared & & $-4.7 * *$ & \\
\hline Age difference ${ }^{a}$ & & & 0.03 \\
\hline Years of man's education & & & $0.31 * * *$ \\
\hline Woman has higher degree of education than man & & & -0.71 \\
\hline Number of children $0-7$ years old & $66.7 * * *$ & $26.12 * * *$ & -0.12 \\
\hline Number of children $7-18$ years old & $27.9 * * *$ & $7.66 * * *$ & -0.16 \\
\hline Number of elderly persons in the household & -2.28 & 1.15 & -0.19 \\
\hline Automobile owned & $9.47^{*}$ & $19 * * *$ & \\
\hline Washing machine owned & -5.15 & 5.81 & \\
\hline Rural & $14.7^{*}$ & -4.65 & 0.49 \\
\hline Moscow - St-Petersburg & 7.6 & $15.5^{* * * *}$ & 0.08 \\
\hline Round 5 & $16.3 * *$ & 4.76 & 0.31 \\
\hline Round 6 & -2.96 & 1.67 & 0.19 \\
\hline Round 8 & -12.54 & -12.42 & 0.02 \\
\hline Ratio1 & $86.32 *$ & -25.8 & \\
\hline Constant & $166.8 * * *$ & $134 * *$ & -1.33 \\
\hline Number of observations & 1729 & 1729 & 2174 \\
\hline
\end{tabular}

* significant at the $10 \%$ level; ** significant at the $5 \%$ level $* * *$ significant at the $1 \%$ level

a Age difference: the difference between the woman's age and the man's age.

The reference categories are: Urban versus Rural, region other than Moscow and St Petersburg, Round 7 for round of observation.

Source: RLMS (rounds 5-8) 